\title{
Effect of NPK (12:12:17) Fertilizer Rates on the Growth and Yield of Cowpea (Vigna unguiculata) Varieties
}

\author{
Gilbert Nwogboduhu Nwokwu \\ Department of Crop Production and Landscape Management, Faculty of Agriculture and Natural Resources \\ Management, Ebonyi State University, P.M.B 053, Abakaliki, Nigeria
}

\begin{abstract}
Field experiments were carried out as $3 \times 4$ factorial at the faculty of Agriculture and Natural Resources Management, Ebonyi State University, Abakaliki in 2016 and 2017 cropping seasons to study the effect of NPK (12:12:17) fertilizer rates on the growth and yield of cowpea varieties (Vigna unguiculata). Results revealed that fertilizer application resulted in significant improvement in plant height, number of leaves per plant, leave area index and reduced days to flowering. Yield components and grain yield were significantly enhanced by the application of fertilizer at $150 \mathrm{~kg} \mathrm{ha}^{-1}$ but varietal effect indicated differential varietal responses to fertilizer application which had significantly practical implications for field production. It was therefore concluded that the application of fertilizer to cowpea is beneficial although in small quantity and genotype dependent. There were positive and significant correlation among growth and yield characters except days to $50 \%$ flowering that was negatively correlated.
\end{abstract}

Keywords: Cowpea, Fertilizer, Growth, NPK, Varieties, Yield.

DOI: $10.7176 / \mathrm{JBAH} / 10-2-03$

Publication date: January $31^{\text {st }} 2020$

\section{Introduction}

Cowpea (Vigna unguiculata L walp) is a tropical annual herbaceous legume which belong to the family papilionaceae (Fabaceae) order Leguminosae and genus Vigna (Singh et al., 1997). The genus Vigna consist of over hundred different species widely found in the tropical and subtropical regions and has great morphological and ecological diversity. It is an important food grain legume for over 200 million people in the dry savanna of tropical Africa. It is particularly important in West Africa with over 9.3 million metric tons of annual production (Oritz, 1998). The grain is a good source of human protein, while the haulms are valuable source of livestock protein (Fatokun, 2002). It is also a source of income for many smallholder farmers in sub-Saharan Africa and contributes to the sustainability of cropping systems and soil fertility improvement in marginal lands through provision of ground cover and plant residue, nitrogen fixation and suppressing weed. However, despite its great importance, grain yield of cowpea crop is low, around $300 \mathrm{~kg} \mathrm{ha}^{-1}$ compared with many other crops, the cowpea has received little attention from plant breeders and a large efforts needs to be made to break the yield barriers and if cowpea production is to keep pace with the other crops, especially cereals, its yield potential must be improved (Anonymous, 2004).

In Nigeria, $80 \%$ of the cowpea produced is mainly in the savanna zone of the country (FAO, 1999). A wide range of seed yields have been recorded for cowpeas but are generally low.

Among factors responsible for the low yields are low soil fertility, as most tropical soils are deficient in essential nutrients particularly N and P (Jones and Wild, 1975). Traditionally, soil fertility in West Africa have been maintained through fallow. However, in Nigeria, intensive cropping and high population pressure are gradually replacing the traditional shifting cultivation that is associated with long fallow and hence low crop yield. The steady decline in food production due to reduced length of fallow on land has prompt farmers to amend soil with different materials such as organic and inorganic in order to enhance plant growth and increase yield (Adepetu, 1997). It has been suggested that organic manure should be used in place of chemical fertilizer to avoid long-term negative effects of chemical fertilizer on the soil (Parr et al., 1990). However, organic manure is usually required in large quantity to sustain crop production and may not be available to the small scale farmers (Nyathi and Campbell, 1995), hence, the need for inorganic fertilizer. The positive effect of the application of inorganic fertilizers on crop yields and yield improvement have been reported (Carsky and Iwuafor, 1999). Although, cowpea symbiotically fixes nitrogen, plant dependent on symbiotically fixed $\mathrm{N}$ may well suffer from temporary $\mathrm{N}$ deficiency during the seedling growth once the cotyledonary reserves have been exhausted.

\section{Materials and Methods}

The field experiments were conducted during 2016 and 2017 cropping seasons at the Research field of the Faculty of Agriculture and Natural Resources Management, Ebonyi State University Abakaliki. The experimental design was $3 \times 4$ factorial laid out in a randomized complete block design (RCDB). The treatments comprised of three cowpea varieties (Sampea 5, 6 and 13) and four rates of NPK 12:12:17 (0, 50, 100 and 150kg $\mathrm{ha}^{-1}$ and was replicated three times. The land was cleared and cultivated manually and the plot measured out and 
pegged. Each plot measured $2 \mathrm{~m} \times 2 \mathrm{~m}\left(4 \mathrm{~m}^{2}\right)$ with $0.5 \mathrm{~m}$ between adjacent plot and $1 \mathrm{~m}$ between replicates. The seeds were sown two seeds per hill at the depth of $2 \mathrm{~cm}$ with the planting distance of $50 \mathrm{~cm} \times 50 \mathrm{~cm}$. Data were collected on the growth and yield parameters and were analysed with a General Linear Model in Minitab and where there were significant differences Turkey's test was used to separate the means. The residuals were tested for normality with the Anderson-Darling test, and where appropriate a transformation was used to improve the fit of the residuals to the normal distribution. Also correlations of the growth and yield parameters were determined in Minitab.

\section{Result and Discussions}

Soils of the area varied in their chemical properties with the Ferric Luvisol having a $\mathrm{P}$ value higher than that of the Ferric Lixisol. Soil nutrients deficiency is wide spread and is a major constraint to crop production (Nwoke et al., 2005; Kisinyo et al., 2011). The P value for the Ferric Luvisol could be attributed to the spatial variation of soil properties which is common. The inability of soils to supply adequate amounts of soil nutrients for plant growth is partly due to extensive losses due to long periods of intense weathering and strong fixation by $\mathrm{Al}$ and Fe oxides prevalent in many tropical soils (Doe, 2006). Organic matter levels of both soils were below the critical value $(<1.7 \%)$ while the exchangeable calcium, sodium and magnesium levels were moderate for cowpea production (Landon, 1996). Fosu and Tetteh (2008) reported soil organic matter level of $0.48 \%$ for soils and soil nitrogen level of between 0.02 and $0.07 \%$ for savanna soils. The soils low organic carbon and total nitrogen contents could be attributed to the high temperatures resulting in high rate of decomposition. It can also be attributed to overgrazing as the farmers release their animals to feed on crop residues soon after harvest making residue incorporation unlikely. Soil organic matter is a major contributor to agricultural production in Africa and it influences soil properties and consequently plant growth.

Growth attributes such as plant height, leaf area index, number of leaves and Days to $50 \%$ flowering were significantly increased by the application of NPK fertilizer. This result is in conformity to the results observed by Krasilnikoff et al. (2003) and Nyoki et al. (2013). This could be attributed to the fact that NPK is required in large quantities in shoot and root tips where metabolism is high and cell division is rapid (Ndakidemi and Dakora, 2007). Thus, an indication that the cowpea varieties utilized the NPK fertilizer applied judiciously in growth and development processes. NPK application also improved all yield attributes taken into consideration in this study: number of pod, pod weight, pod length, seed weight, number of seeds and seed yield. These were found to be significantly different at 0.05 level of significance and this is in conformity with the findings of other workers (Okeleye and Okelana, 2000; Haruna and Usman, 2013; Odundo et al., 2001; Ntare and Bationo, 2002; Nyoki et al., 2013; Singh et al., 2011 and Ndor et al., 2012) who also discovered significant increase in yield of cowpea in response to phosphorus application. However, Agboola and Obigbesan (2001) reported that phosphorus application did not significantly increase cowpea yield but rather enhanced nodulation and phosphorus content of leaf and stem. Highest value in all the yield characters measured was observed in variety sampea 5 or 13 at NPK fertilizer rate of $150 \mathrm{~kg}$ ha-1, this contradicts the findings of Haruna and Usman (2013) who recorded highest yield at $30 \mathrm{~kg}$ ha-1 in their experiment and Singh et al., (2011) who reported highest yield at 60kgha-1 and suggested that that may be the optimum as further application of phosphorus may or may not increase yield of cowpea. The significant response of the measured yield characters of cowpea to phosphorus application could be attributed to the role of phosphorus in seed formation and grain filling (Haruna, 2011).

Table 1:Physcial and chemical properties of soil (0-30) from the experimental site

\begin{tabular}{|l|l|}
\hline Soil Properties & Quantity \\
\hline Sand $(\mathrm{g} / \mathrm{kg})$ & 112 \\
\hline Silt $(\mathrm{g} / \mathrm{kg})$ & 273 \\
\hline Clay $(\mathrm{g} / \mathrm{kg})$ & 152 \\
\hline Textural Class & Loam \\
\hline Chemical Properties & \\
\hline ph in $0.01 \mathrm{M} \mathrm{CaCL} 2$ & 3.21 \\
\hline Organic Carbon $(\mathrm{g} / \mathrm{kg})$ & 10.3 \\
\hline Total Nitrogen $(\mathrm{g} / \mathrm{kg})$ & 0.5 \\
\hline Available P $(\mathrm{mg} / \mathrm{kg})$ & 2.02 \\
\hline Exchangeable Cation $(\mathbf{c m o l} / \mathbf{k g})$ & \\
\hline $\mathrm{K}$ & 0.11 \\
\hline $\mathrm{Mg}$ & 0.42 \\
\hline $\mathrm{Ca}$ & 50 \\
\hline $\mathrm{Na}$ & 5.3 \\
\hline $\mathrm{CEC}$ & 2.34 \\
\hline
\end{tabular}


Table 2: Effect of NPK 12:12:17 Fertilizer rates on the growth and yield characters of cowpea varieties

\begin{tabular}{|c|c|c|c|c|c|c|c|c|c|c|}
\hline Treatments & $\begin{array}{l}\text { Height } \\
(\mathrm{Cm})\end{array}$ & $\begin{array}{l}\text { No of } \\
\text { leaves }\end{array}$ & $\begin{array}{l}\text { Leave } \\
\text { area } \\
\text { index }\end{array}$ & $\begin{array}{l}\text { Days } 50 \% \\
\text { flowering }\end{array}$ & $\begin{array}{l}\text { No of } \\
\text { Pod }\end{array}$ & $\begin{array}{l}\text { Pod } \\
\text { Lengt } \\
\mathrm{h}\end{array}$ & $\begin{array}{l}\text { Pod } \\
\text { weigh } \\
\mathrm{t} \\
(\mathrm{kg})\end{array}$ & $\begin{array}{l}\text { No of } \\
\text { Seeds }\end{array}$ & $\begin{array}{l}\text { Seed } \\
\text { Weight } \\
\text { (g) }\end{array}$ & $\begin{array}{l}\text { Yield } \\
\left(\mathrm{Kg} \mathrm{ha}^{1}\right)\end{array}$ \\
\hline \multicolumn{11}{|l|}{$\begin{array}{l}\text { NPK rates } \\
\left(\text { kg ha }^{1}\right)\end{array}$} \\
\hline 0 & $34.29 \mathrm{~d}$ & $17.02 \mathrm{c}$ & $3,30 \mathrm{~d}$ & $42.78 \mathrm{a}$ & $5,33 \mathrm{~d}$ & $4.44 \mathrm{c}$ & $0.42 \mathrm{~d}$ & $4.22 \mathrm{~d}$ & $0.31 \mathrm{~d}$ & $4.48 \mathrm{~d}$ \\
\hline 50 & $40.20 \mathrm{c}$ & $29.97 b$ & $4,07 \mathrm{c}$ & $32.22 b$ & $7.00 \mathrm{c}$ & $5.11 \mathrm{~b}$ & $0.61 \mathrm{c}$ & $5.44 c$ & $0.57 \mathrm{c}$ & $5.70 \mathrm{c}$ \\
\hline 100 & $44.53 b$ & $30.39 \mathrm{~b}$ & $4.5 \mathrm{~b}$ & $32.33 b$ & $7.89 b$ & $5.33 b$ & $0.77 b$ & $7.11 \mathrm{~b}$ & $0.63 b$ & $6.76 \mathrm{~b}$ \\
\hline 150 & $50.49 \mathrm{a}$ & $38.37 \mathrm{a}$ & $5.40 \mathrm{a}$ & $30.89 \mathrm{c}$ & $11.0 \mathrm{a}$ & $8.67 \mathrm{a}$ & $1.32 \mathrm{a}$ & $9.11 \mathrm{a}$ & $1.03 \mathrm{a}$ & $7.54 \mathrm{a}$ \\
\hline $\mathrm{SE} \pm$ & 0.95 & 1,08 & 0.24 & 0.48 & 0.28 & 0.27 & 0.03 & 0.13 & 0.06 & 0.59 \\
\hline \multicolumn{11}{|l|}{ Varieties } \\
\hline Sampea 5 & $42.73 a$ & $28.75 b$ & $4.28 \mathrm{a}$ & $33.83 \mathrm{c}$ & $7.08 \mathrm{c}$ & $5.42 \mathrm{c}$ & $0.77 \mathrm{a}$ & $6.25 c$ & $0.68 \mathrm{a}$ & $6.57 \mathrm{a}$ \\
\hline Sampea 6 & $42.14 \mathrm{a}$ & $29.72 \mathrm{a}$ & $4.41 \mathrm{a}$ & $34.17 \mathrm{~b}$ & $8.00 \mathrm{~b}$ & $6.00 \mathrm{~b}$ & $0.78 \mathrm{a}$ & $6.67 \mathrm{a}$ & $0.60 \mathrm{~b}$ & $5.22 \mathrm{~b}$ \\
\hline Sampea 13 & $42.27 \mathrm{a}$ & $28.35 b$ & $4.28 \mathrm{a}$ & $35.67 \mathrm{a}$ & $8.33 a$ & $6.25 a$ & $0.80 \mathrm{a}$ & $6.50 \mathrm{~b}$ & $0.62 b$ & $6.58 \mathrm{a}$ \\
\hline $\mathrm{SE} \pm$ & 0.83 & 0.94 & 0.21 & 0.41 & 0.24 & 0.23 & 0.03 & 0.11 & 0.05 & 0.51 \\
\hline
\end{tabular}

Means followed by same letter (s) within same column and treatment group are not statistically different at 5\% level of probability using Turkey's test.

Table 3 shows the relationship that exist in growth, yield and yield components of cowpea varieties. The significant and highly positive correlation between yield characters and its growth characters signified the importance of these characters in assimilate production. Larger canopy cover means greater interception of light energy and higher rate of photosynthesis. The parameter with the strongest relationship with yield was pod weight followed by number of seed while the weakest association with yield was days to $50 \%$ flowering that was negative, though was significant. The positive association of plant height via some growth and yield characters indicate a sort of source -sink relationship because assimilates produced had to be shared between the foliage, root and seeds hence the reason for weaker relationship because of competition for assimilates. These factors determine the vegetative photosynthetic surface area for the manufacture and translocation of assimilates to seeds which constitute yield. The positive and highly relationship between one character and other indicated interdependency between the characters, Lawa (2000) reported a significant inter-relationship among growth and yield attributes. The negative and significant association observed in days to $50 \%$ flowering suggest that the character was not the main component of seed yield due to combination of the treatments such as NPK rates which resulted in competition for limited resources.

Table 3: Correlation of growth and yield components of cowpea varieties

\begin{tabular}{|c|c|c|c|c|c|c|c|c|c|c|c|}
\hline 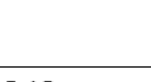 & Height & \multicolumn{2}{|c|}{ LAI No of leave } & Days $50 \% \mathrm{~F}$ & No of pod & $\begin{array}{l}\text { pod } \\
\text { length }\end{array}$ & \multicolumn{2}{|c|}{ no of seed } & \multirow[t]{2}{*}{ seed weight } & \multirow[t]{2}{*}{ pod weight } & \multirow[t]{2}{*}{ yield } \\
\hline & 0.652 & & & & & & & & & & \\
\hline & 0.000 & & & & & & & & & & \\
\hline \multirow[t]{2}{*}{ No of leave } & 0.856 & 0.683 & & & & & & & & & \\
\hline & 0.000 & 0.000 & & & & & & & & & \\
\hline \multirow[t]{2}{*}{ Days $50 \% \mathrm{~F}$} & -0.752 & -0.611 & -0.794 & & & & & & & & \\
\hline & 0.000 & 0.000 & 0.000 & & & & & & & & \\
\hline \multirow[t]{2}{*}{ No of pod } & 0.784 & 0.620 & 0.801 & -0.570 & & & & & & & \\
\hline & 0.000 & 0.000 & 0.000 & 0.000 & & & & & & & \\
\hline \multirow[t]{2}{*}{ pod length } & 0.735 & 0.668 & 0.686 & -0.503 & 0.778 & & & & & & \\
\hline & 0.000 & 0.000 & 0.000 & 0.002 & 0.000 & & & & & & \\
\hline \multirow[t]{2}{*}{ No of seed } & 0.842 & 0.708 & 0.765 & -0.694 & 0.840 & 0.810 & & & & & \\
\hline & 0.000 & 0.000 & 0.000 & 0.000 & 0.000 & 0.000 & & & & & \\
\hline \multirow[t]{2}{*}{ seed weight } & 0.705 & 0.588 & 0.655 & -0.704 & 0.723 & 0.740 & 0.786 & & & & \\
\hline & 0.000 & 0.000 & 0.000 & 0.000 & 0.000 & 0.000 & 0.000 & & & & \\
\hline \multirow[t]{2}{*}{ pod weight } & 0.877 & 0.723 & 0.795 & -0.635 & 0.817 & 0.859 & 0.884 & 0.793 & & & \\
\hline & 0.000 & 0.000 & 0.000 & 0.000 & 0.000 & 0.000 & 0.000 & & 0.000 & & \\
\hline \multirow[t]{2}{*}{ yield } & 0.445 & 0.353 & 0.378 & -0.430 & 0.373 & 0.254 & 0.501 & 0.366 & 0.327 & & \\
\hline & 0.007 & 0.035 & 0.023 & 0.009 & 0.025 & 0.136 & 0.002 & 0.028 & 0.052 & & \\
\hline
\end{tabular}

The values below each of the means are the p- values at $5 \%$ 


\section{Conclusion}

The observed variations in the performance of the cowpea varieties used could provide a basis for selecting cowpea lines with greater agronomic efficiency in deficient soil to reduce fertilizer cost. These variations could be important for selecting varieties suitable for a range of soil conditions as well as to release to farmers on large scale production. It could be concluded that Sampea 5 or 13 which were statistically similar in yield and NPK application rate of $150 \mathrm{~kg} \mathrm{ha}^{-1}$ is ideal for the area and is therefore recommended for farmers in the study area for enhancement of cowpea production.

\section{References}

Adepetu, J.A.1997.Soil and Nigeria food security. Inaugural Lecture Series 119. Obafemi Awolowo University, Ile-Ife, Nigeria .pp 19.

Agboola, A. A. and Obigbesan, G. O., (2001). Effect of different sources and levels of P on the Performance and P uptake of Ife Brown variety of cowpea. Ghana J. of Agric. Sci., 10 (1 71-75.

Anonymous, 2004. Vigna Germplasm: Current status and future Needs, A report prepared by the Vigna Crop Germplasm Committee pp. 1-11

Carsky, R.J. and Iwuafor, E.N.O. (1999). Contribution of soil fertility Research/maintenance to Improved maize production and productivity in sub Saharan Africa. In Badu-Apraku. B., Fakorede, M.A.B., Ouedraogo, M. and Quin F.M. (Eds.). Strategy for sustainable maize Production in West and Central Africa. Proceedings of a Regional Maize Workshop, 21-25 April 1997, IITA-Cotonou, Republic of Benin.

Doe, R. 2006. Future challenges in P fertilizer and the environment. 18th World Congress of Soil Science July 915, Philadelphia, Pennsylvania, USA

FAO, 1999. Production year book, FAO Rome.

Fatokun, A.C., (2002). Breeding Cowpea for Resistance to Insects Pests, Attempted Crosses between Cowpea and Vignavexillata. In: Challenges and Opportunities for Enhancing Sustainable Cowpea Production, Fatokun, C.A., Tarawali, S. A., Singh, B. B., Kormawa, P. M, \& Tamo, M. (Ends). International Institute of Tropical Agriculture (IITA) Ibadan, Nigeria, pp. 52-61

Fosu, M. and Tetteh, F.M. (2008). Soil Organic Matter and Nitrogen in Ghanaian Soils: A review pp. 67-81. In Bationo, A., Tabo, R., Waswa, B., Okeyo. J., Kihara, J., Fosu, M. and Kabore, SCO. (Eds.). Synthesis of soil, water and nutrient management Research in the Volta Basin. CIAT-TSBF Publ. Nairobi, Kenya

Haruna, I. M., (2011). Dry matter partitioning and grain yield potential in sesame (Sesamum Indicum .L.) as influenced by poultry Phosphorus at Samaru, Nigeria. J. Agric. Technol., 7: 1571-1577.

Haruna, I. M., and Usman, A., (2013). Agronomic efficiency of (Vigna unguiculata (L.) Walp) under varying Phosphorus rates in Lafia, Nassarawa State, Nigeria. Asian J. Of Crop Sci., 5: 209-215

Jones, M.I and Wild, A.1975. Soil of West African Savanna. The maintenance and improvement of their fertility. Technical communication No 55 of the Commonwealth Bureau of soils. Harpenden UK. Commonwealth Agricultural Bureau (CAB), Famham Royal, UK.PP246.

Kisinyo, P.O., Ng'etich, W.K., Othieno, C.O., Kaleb J.R., and Opile, W.R. (2011). Phosphorus Depletion should the ACP countries be concerned? What are the Current issues for future Research and policy? www.knowledge.cta.int /en/cContent/view/full/13715. Accessed June 2013.

Krasilnikoff, G., Gahoonia, T., and Erik-Nelson, N., (2003). Variation in Phosphorus Uptake by Genotypes of cowpea (Vigna unguiculata (L.) Walp) due to differences in root and root hair length and induced rhizosphere processes. Plant and Soil. 251: 8391.

Landon, J.R. (1996). Booker Tropical soil Manual. A handbook for soil survey and Agricultural Land evaluation in the tropics and sub-tropics. Longman, New York London. pp. 431.

Lawal, M.I (2000). Growth, yield and yield components of lowland rice (Oryza sativa L as affected by nitrogen levels, placement methods and planting patterns. Thesis Submitted Ahmad Bello University, Zaria.

Ndakidemi, P. A. and Dakora, F. D., (2007). Yield components of nodulated cowpea (Vigna unguiculata (L.) Walp) and maize (Zea mays) plants grown with exogenous phosphorus in different cropping systems. Aust. J. Exp. Agric. 47: 587-590.

Ndor E., Dauda, N., Abimuku, E., Azagatu, D., Anzaku, H., (2012). Effect of phosphorus Fertilizer and spacing on growth, nodulation count and Yield of cowpea (Vigna unguiculata (L.) Walp) in southern guinea Savannah of Nigeria. Asian J. Agric. Sci., 4: 254-257.

Nwoke, O.C., Diel, J., Abaidoo, R. and Sanginga, N. (2005). Low phosphorus availability in West African moist savanna soils: Effects of sparing soluble P sources on the growth of soybean, Cowpea and maize. African Crop Science Conference Proceedings 7: 1157-1161.

Ntare, B. R. and Bationo, A., (2002). Effects of phosphorus on yield of Cowpea cultivars Intercropped with pearl millet on Psammentic Paleustalf in Niger. Spring. Link 32(2): 143-147.

Nyathi, P. \& B.M. Campbell, (1995). The effect of tree leaf litter, manure, inorganic Fertilizer and Their combination on above ground production and grain yield of Maize. Africa Journal Crop Science, 3:451-456 
Nyoki, D., Patrick, A., Ndakidemi, R., (2013). Economic benefits of Brady rhizobium Japonicum Inoculation and phosphorus Supplementation in cowpea (Vigna unguiculata (L.) Walp) Grown in Northern Tanzania. American J. of Research comm., 1(11): 173189.

Okeleye, K. A. and Okelana, M. A O., (2000). Effect of phosphorus Fertilizer on Nodulation, Growth, and yield of cowpea (Vigna unguiculata) varieties. Indian J. of Agric. Sci., 67(1): 10-12.

Oritz, R. 1998. Cowpea from Nigeria: A Silent food revolution. Outlook Agric.27:125-128.

Parr, J.F., Papendick, R.I., Herrick, S.B. \& Meyer, R.E., (1990). The use of cover crops.

Singh, B.B., Mohan-Raj, D.R., Dashiel, K.E. and Jackai, L.E.N. (1997). Advances in Cowpea Research- Post Harvest Storage of Cowpea in Sub-Saharan Africa. I.I.T.A./JIRCA Publication, Ibadan, Nigeria, pp. 302312.

Singh, A., Baoule, A. L., Ahmed, H. G., Aliyu, U., and Sokoto, M. B., (2011). Influence of Phosphorus on the performance of cowpea (Vigna unguiculata (L.) Walp) varieties in the Sudan savannah of Nigeria. Agric.Sci, 2: 313-317. 